\title{
Continuing education in health from the perspective of Augustine of Hippo
}

\author{
Educação permanente em saúde sob a perspectiva de Agostinho de Hipona \\ Educación continua en salud según la perspectiva de Agostinho de Hipona
}

\section{Fabíola Chaves Fernandes', Elaine Antunes Cortez', Daniel Laprovita", Lidiane Peixoto de Almeida", Aline Figueiredo Ferreira", Marcos Paulo Fonseca Corvino"II \\ ' Universidade Federal Fluminense, Aurora de Afonso Costa School of Nursing, Postgraduate Program in Nursing. Niterói, Rio de Janeiro, Brazil. \\ "Universidade Federal Fluminense, Aurora de Afonso Costa School of Nursing, Professional Master's Program in Nursing. Niterói, Rio de Janeiro, Brazil. \\ II' Universidade Federal Fluminense, Institute of Collective Health, Department of Health Planning. Niterói, Rio de Janeiro, Brazil.}

How to cite this article:

Fernandes FC, Cortez EA, Laprovita D, Almeida LP, Ferreira AF, Corvino MPF. Educação permanente em saúde sob a perspectiva de Agostinho de Hipona. Rev Bras Enferm [Internet]. 2017;70(3):656-61.

DOI: http://dx.doi.org/10.1590/0034-7167-2016-0484

Submission: 08-25-2016 Approval: 01-18-2017

\begin{abstract}
Objective: To reflect about continuing education from the perspective of Augustine of Hippo and his theories based on the construction of knowledge and the learning process. Method: This is a theoretical reflection study whose aim is to propose dimensions of analysis, emphasizing the history and challenges of continuing education. Such dimensions analyze the production of knowledge in Augustinian pedagogy, its historical aspects and its close relationship with lifelong education in health professions. Results: The results show the difficulty of continuing education to reach adequate importance in health services, and that of academia in appropriating the thoughts of renowned philosophers such as Augustine. This is a result of ignorance about the convergence of these principles and their relevance. Final considerations: Continuing education and Augustinian pedagogy walk hand in hand in terms of care, meeting the needs that originate from practice and that are reflected in it, challenging isolated knowledge and putting different areas of knowledge to work together.
\end{abstract}

Descriptors: Education, Continued; Saints; Health Education; Education; Public Health Policy.

\section{RESUMO}

Objetivo: Refletir sobre a educação permanente na perspectiva de Agostinho de Hipona e suas teorias pautadas na construção do conhecimento e no processo de aprendizagem. Método: Trata-se de uma reflexão teórica cujo intuito é propor dimensões de análise, enfatizando a história e os desafios da educação permanente. Tais dimensões analisam a produção do conhecimento na pedagogia agostiniana, seus aspectos históricos e sua relação próxima com a educação permanente em saúde. Resultados: Revela a dificuldade da educação permanente em ter sua dimensão alcançada noserviço de saúde, tal qual a da academia de apropriar-se do pensamento de filósofos renomados como Agostinho, fruto do desconhecimento da convergência desses pressupostos e de sua relevância. Considerações Finais: Considera-se que a educação permanente e a pedagogia agostiniana caminham juntas no cuidar, atendendo às necessidades advindas da prática e nela refletida, confrontando os saberes isolados e com eles operando em conjunto. Descritores: Educação Continuada; Santos; Educação em Saúde; Educação; Políticas Públicas de Saúde.

\section{RESUMEN}

Objetivo: Reflexionar sobre la educación permanente según la perspectiva de Agostinho de Hipona y sus teorías basadas en la construcción del conocimiento y el proceso de aprendizaje. Método: Reflexión teórica apuntando a proponer dimensionas de análisis, destacando la historia y los desafíos de la educación continua. Dichas dimensiones analizan la producción del conocimiento en la pedagogía agostiniana, sus aspectos históricos y su relación cercana a la educación continua en salud. Resultados: Revelan la dificultad de la educación continua para que su dimensión se alcance en el servicio de salud, y la de que los académicos se apropien del pensamiento de filósofos renombrados como Agostinho, merced al desconocimiento de la convergencia de tales presupuestos y su relevancia. Consideraciones finales: La educación continua y la pedagogía agostiniana 
caminan juntas en el cuidar, atendiendo las necesidades devenidas de la práctica reflejada en ella, confrontando los saberes aislados y operando conjuntamente con ellos.

Descriptores: Educación Continua; Santos; Educación en Salud; Educación; Políticas Públicas de Salud.

CORRESPONDING AUTHOR Fabíola Chaves Fernandes E-mail: fabconsidera@bol.com.br

\section{INTRODUCTION}

Considering that every era develops different forms of education that result from its social needs, the present article discusses the convergence of Augustinian thought, which dates back to the 5th century, with Brazil's national policy for continuing health education, a very current theme.

This study is justified due to the difficulty of continuing education in reaching the necessary importance in health services and of health education appropriating the ideas of renowned philosophers such as Augustine, due to ignorance of the convergence of their assumptions and of their relevance. Thus, this study contributes to the health area by discussing other pedagogical approaches that are in consonance with current and pertinent themes.

Based on the understanding that education always aims to correspond to cultural, religious, economic, and political values of a given period, this reflection article uses excerpts from the life of Augustine of Hippo and his historical context to establish a parallel with the pedagogical aspects of Brazil's national continuing education policy in health professions, seeking points of convergence. The aim of this article is to reflect about continuing education from the perspective of Augustine and his theories based on the construction of knowledge in the teaching-learning process. Thus, the guiding question was: What aspects of Augustine's philosophy, which dates back to the $5^{\text {th }}$ century, are in agreement with the current national policy for continuing health education?

\section{METHOD}

This is a reflection paper based on the theoretical framework of Augustine of Hippo and Brazil's national policy for continuing health education, constituting two categories of analysis: "The historical aspect of education in Augustine of Hippo" and the "The historical aspect of the national policy for continuing education in the health professions."

The hypothesis explored is: The production of knowledge in Augustinian pedagogy and its close relationship to continuing education can contribute to health education, given the convergence of their ideas.

As data sources, the researchers used Augustine's text "The Confessions", "The Measure of the Soul", and "The Happy Life", in addition to the document containing the national policy for continuing education in health and articles found in the LILACs database on the theme published in the last five years. After data collection, the data were grouped in two categories, which were described based on Augustine's texts, Brazilian legislation, and the scientific articles. Data analysis was conducted from the perspective of Augustine's ideological affluence and the affinity of his actions, attitudes, and thoughts.

\section{RESULTS}

This study presents two categories that emerged from the absence of scientific production addressing the convergence of Augustinian education and the national policy for continuing health education. Thus, the article presents Augustine philosophy within its historical context, and continuing education, also within its legally established context and in association with its application, such as in articles that present its practical application, and its origin, i.e., the law behind the policy.

\section{Historical aspects of education in Augustine of Hippo}

The philosophy of Augustine originates from the unrest experienced throughout his educational life. Son of pagan Patrice and Saint Monica, he had an unruly youth, adhering to Manichaeism, a religion founded by Mani, on the dualism of good versus evil, and the skeptical tradition, neither of which were capable of adequately removing his doubt ${ }^{(1)}$.

It is important to be familiar with the life of Augustine of Hippo, as it directly influenced his work. His most famous and autobiographic book, "The Confessions", in which he demonstrates that infants learn their first words by hearing them repeatedly in phrases and in the right context, until they are noticed as the objects they signify. Words are first memorized, then repeated, and in a second phase of education, they acquire meaning ${ }^{(1)}$. In the case of "The Confessions", the conversion or transformation had already taken place. Thus, this transformation is witnessed to affirm it to others, and not to God, and, through this, the confessions of his sins are used as a testimony of the transformation performed by God in his being, a process that can thus become an educational process with significant gain for readers ${ }^{(2)}$.

Augustine defends that the learning process in childhood occurs through deduction and in a natural manner. Thus, by frequent repetition, words gain meaning and, little by little, start to represent reality ${ }^{1}$. According to this philosopher, children become part of society through the use of communication signs, depending on the authority of their parents and elders ${ }^{(1)}$.

At the time, studying was a burden to him due to its obligatory nature, even though he knew it was a good thing. However, he believed that no one could choose good against their will. Furthermore, those who obliged him to study did not display adequate behaviors and had no other objective than to encourage him to shine in this world, standing out in the language arts and gaining human honors and fake wealth. He called them word merchants, as they attributed value to letters of the alphabet by convention $^{(1)}$. Furthermore, he believed that talent and language 
should be used in things beyond academic success, aimed the common good; just as no one laughs alone, no one gains alone from the proposed educational process ${ }^{(1)}$.

In his description of the knowledge discovery process, Augustine defended that it was better to believe in those who teach truthfully than those who dictate rules and orders, or who are cult-worthy, which was the profile of those who detained knowledge at the time. Teachings only make sense through each person's inherent understanding and do not need to be presented through order or method. Instead, they must be conveyed in a way that makes sense and that enables its retention, rejection or avoidance, at one's own discretion ${ }^{(3)}$.

On coming into contact with Cicero's "Hortensius", Augustine sailed into high seas, dedicating himself entirely to philosophy. Over time, he found people who he considered cult-worthy and remained in the calm and the comfortable cocoon of academic teachings. Then, by retaking control of the wheel of his own vessel, fighting against winds and being slowed down by detours, he dove headfirst into the bosom of philosophy ${ }^{(3)}$.

On taking control of his vessel, Augustine brings attention to the power of the autonomy of self-directed discovery, which does not require being contested or convince, only reading and studying ${ }^{(1)}$. His pedagogy conduces to learning through one's own reasoning, with the desire only to instruct understanding, so that students are well prepared in formulating conclusive reasoning ${ }^{(4)}$. He called this food for the soul, the intelligence of things and science. These must be nurtured with care and through thoughts in order for something to be perceived, without experiencing deprivation and hunger of the spirit ${ }^{(3)}$. According to Augustinian theory, learning requires an intermediary between the body and the source of true knowledge. Through illumination, humans can know the truth, as revealed in the Gospel, to which he had been converted and by which he was motivated ${ }^{(4)}$.

Even though he was motivated by faith, Augustine broke with the paradigm that his philosophy was intentionally religious, and by consequence, of difficult acceptance by the secular academic environment, considering that his conversion took place after his academic and professional training.

\section{Historical aspect of the national policy for continuing health education}

Before describing the policy's historical context, it is important to conceptualize continuing education. It is a pedagogical concept in the health sector that encompasses the relationship between teaching and actions or services, and between academia and health care $^{(5)}$. The Brazilian health reform expanded this concept to include the relationships between training and sectorial management, and institutional development and social control in health. In this model regional specificities must be taken into account to strengthen decentralization and reach comprehensiveness of care ${ }^{(5)}$.

The model was born out of divergences among political thinkers in the health area, fruit of an institutional need to continuously foster knowledge specific to health. This originates from the multiplicity of knowledge and aims at comprehensiveness of health care, as discussed in Law 8080/90. The policy for continuing health education adopts a participative logic for education, through the creation and constitution of positions in ongoing committees for the integration of health services and teaching institutions ${ }^{(5)}$.

The integrating action of continuing education in the Brazilian Unified Health System (SUS) is a pedagogical form of conducting activities in the health sector. With Resolution 330/2003-NOB/RH-SUS, of November 4, 2003, continuing health education was implemented in all Brazilian states as a strategy by SUS to train and develop workers in this sector ${ }^{(5)}$. Its scope was expanded with the intention of using continuing education to reorganize work processes at different levels of care, such as emergency services ${ }^{(6)}$.

Based on article 200 of the Federal Constitution, which provides for issues related to health education within the competency of the SUS, the aim of the national policy for continuing health education is to ensure that health worker training and qualification are adapted to the actual needs of users $^{(5)}$. This policy intends to improve the care practice of professionals, respecting user needs and giving them autonomy, especially through the use of different methodologies, always striving toward comprehensiveness. However, there are still gaps in the implementation of this process ${ }^{(7)}$.

The intention of continuing health education is to connect teams. In primary care, teams are wide reaching and encompassing, however educational processes are still on a one-off basis. The difficulties presented by regional variations and also access to technology are due to infrastructure problems, and not lack of team interest or adherence ${ }^{(8)}$.

In continuing education, the educational effort aims to bring education closer to daily life, exploring the educational potential of the work situation. The purpose is to transform work situations into learning, by reflectively analyzing problems in practice, valuing the work process, and including all professional categories ${ }^{(5)}$. When teaching is coupled with practice, perspectives shift to other educational contexts, in which education can promote the autonomy of subjects and contact with reality, thus decreasing the extenuating, distressing and stressful nature of the educational process ${ }^{(9)}$.

Coordination of different teaching and service sectors with the community, in addition to coupling theory and practice and using active methodologies in the teaching-learning process, such as problematizing situations and social context, enables all involved to become aware of the population's social and health needs. This then provides them the possibility of experiencing the reality of health service users and critically reflect on their social role, an aspect that facilitates learning and makes it more interesting ${ }^{(10)}$. Thus, the educational effort proposed only makes sense if it triggers management to make plans that integrate, qualify and raise awareness about SUS actions, serving as the basis for transformative decision making, an authority attributed to managers ${ }^{(5)}$.

The bill was passed and many actions have been executed, but the reality is still distant from the ideal conditions of user care and working conditions of health professionals. The fight to ensure the universalization of health care and the quality of its service must continue and, to this end, this study suggests using the tool of continuing education coupled with 
Augustine methodology, with the intention of humanizing the proposed educational moment.

\section{DISCUSSION}

As described in the objective, in order to reflect about continuing education from the perspective of Augustine of Hippo and his theories based in the construction of knowledge and the learning process, this article established a parallel between his theories and the policy to then reach common ground. In this way, his thoughts can be better understood and consequently more used in health education.

Augustine's experience shows that he believed more in those who taught with truth than those who dictated orders as truth ${ }^{(3)}$.

In this direction, the national policy for continuing education defines learning as the development of new capacities or criteria to address problems, or a review of existing capacities and criteria that can be hindering the resolution of such problems ${ }^{(5)}$.

In the school model of continuing education, learning is organized around disciplines and there seems to be coordination between what is done and what is said during the training process. However, this form of education does not necessarily connect practical problems to the behaviors that must be mobilized and modified through learning. Capacity building is not always collective nor does it always translate into organizational learning(5).

This conflict is not present in Augustine's work, as he only wished to enjoy full happiness through a tranquil life in God. Not the lesser form of happiness, but that desired by the best part of $\operatorname{him}^{(4)}$.

The same is true in continuing education: different sources of knowledge are not conflicting, as the objective is to bring them together and reduce divergences in favor of comprehensive care, not restricted to any professional category. When care professionals are considered as the actors and constructors of their own knowledge, the work process can be analyzed reflexively and then hopefully, they can achieve institutional change, in the same way that Augustine aimed to achieve ultimate happiness ${ }^{(5)}$.

Augustine reveals this empowerment, heart of continuing education, through the close relationship he establishes between master and disciple in his dialogue with Evodius. The relationship in the text enables the student to reach mastery of what the author proclaims as the truth, creating adequate conditions through affectionate and Socratic guidance. Even though Evodius disagrees with the master's point of view, admitting so in the text, the master considers learning to be a process of remembering, in that true knowledge is innate, deposited in the soul by $\operatorname{God}^{(4)}$.

Taking control of the wheel and conducting one's vessel to the port of knowledge demonstrates the need for an effective mechanism of continuing education that develops sufficient autonomy to launch oneself to sea ${ }^{(3)}$.

The aim of continuing education is the development of one's own truth, through the argument from reason, which leads to persuasion. First, persuasion is individual, then collective, and capable of reaching understanding, and then, ripen as education ${ }^{(4)}$. Augustine defends that it is necessary to admit that one is not satiated while on the search, and the measure to be aimed for it is our own measure, as a cohesive group ${ }^{(3)}$.

On reporting his aversion to Greek, Augustine reveals that the difficulty of learning something totally foreign resulted in a bitter learning process that should have been sweet. In turn, he learned Latin without the pressure of punishment, driven by his heart, and not from those who taught Latin, but those who spoke the language ${ }^{(1)}$. Continuing education avoids the imposition of any process, mechanism, or strategy. It also avoids acting prescriptively or offering education health management models, taking into account the autonomy, specificities, and the work already developed by administrative spheres ${ }^{(5)}$.

Thus, it is important to use significant learning in continuing health education, because based on the inter-relation between professional experience and educational practice, the teachinglearning process occurs continuously and through the exchange of experiences. Just as in continuing education, practice is an essential element in education and vice versa, in that learning and teaching are incorporated to the routine of work processes, favoring the transformation of professional practices ${ }^{(5)}$.

The Augustinian method is Socratic, in that it develops a theme based on comparisons and questions. This leads the interlocutors to form their own deductions, being conducted and guided by a progression of ideas with a well-planned finality ${ }^{(4)}$.

In the same way, continuing education does not aim to form new habits, which are merely repeated, but to transform activities in practice by fostering a new way of thinking or acting. Thus, it cannot be implemented occasionally or spontaneously, but rather needs an educational intervention to guide participants to engage in critical discussion, involving the entire group. In this way, they can incorporate learning and teaching to the daily routine of organizations ${ }^{(5)}$.

Augustinian education proposes a process of interiorization, in which the soul, a unit endowed with reason, governs a body ${ }^{(4)}$. Thus, learning is only possible from within, so that the knowledge received from the senses undergoes an enlightenment process and is understood through it. By reading, students learn the truth for themselves ${ }^{(1)}$. The knowledge of the truth is only possible through inner reflection, which is why Augustine education is referred to as self-educational: revealed truth, or true wisdom, is found within the soul itself ${ }^{(1)}$. Actually, this issue is subtle and requires more capable eyes: those of the mind, which provide a more expansive view and that should be guided by masters in the educational process ${ }^{(4)}$.

This more expansive view occurs through temperance, which originates from good proportionality, and modesty, which originates from measure. Together, they confer meaning to plenitude. Augustine defines plenitude as wisdom itself, the result of the search for balance, so that something potentially important does not suffer from excess or is reduced to inferiority ${ }^{(3)}$.

When questioned about the potential of the soul, Augustine explained that knowledge must not be diminished. The Hercules myth refers to the paradigm of small stature and great power. According to Augustine, the growth of the body that takes place with the years does not imply growth of the soul, or its improvement. Furthermore, virtues or moral qualities do 
not refer specifically to space, but to the power or strength of the soul. The growth of the soul is not measured materially, but rather in terms of its potentiality ${ }^{(4)}$.

Regarding potentiality, Augustine referred to that which reveals quality and not dimension, or size. Thus, he suggested not paying heed to that which is visible, as potentiality is superior to the material dimension, or in this case, curricular dimension $^{(4)}$.

Continuing health education breaks with the trend of reducing education to a mere inventory of techniques. In this model, it is not the parts that must be modified, but institutions, as these are linked to roles and representations that have been internalized by each of those involved. Thus, change is behavioral, conceptual and practical ${ }^{(5)}$.

Given that individuals are mortal and transitory beings, change occurs internally, as the impressions recorded in each thing endure even after the events have passed. Therefore, we learn by giving credit to others' intelligence, but later through memories, defined by numerous images presented by different perceptions. These are recognized by the soul and harnessed as true, and entrusted to the spirit, like a depot. Sometimes it is so hidden and buried that students need the help of another person to extract the truth with guiding questions ${ }^{(1)}$.

The national policy for continuing education is aimed at development and institutional change of teams and social groups. This entails guiding the transformation of collective practice, reaching a diversity of actors, and not just one professional category. The purpose of the policy is to find a joint solution for problems that originate from daily practice and are reflected in $\mathrm{it}^{(5)}$.

Thus, the effectiveness of the educational process proposed by the national policy for continuing health education can only take place by conquering autonomy. Such autonomy leads to the construction of one's own transformational path, which requires dignified and proactive attitudes through which professionals can form relationships with people from distinct cultures in the work process to which they belong.

\section{Study limitations}

The literature in the health education about the teachings of Augustine as a pedagogical possibility in association with continuing health education is scarce. A limitation of this study includes the difficulty experienced by academia in appropriating the thought of this philosopher, restricting possibilities of unparalleled wisdom, based on concepts currently used by continuing education.

\section{Contribution to the health area}

The dialogue proposed between the two theoretical frameworks addressed in this article contributes with new knowledge in the field of continuing health education. Furthermore, given that both Augustine thought and the national policy result in a common objective - the search for autonomy - and such dialogue represents a new option for those willing to problematize issues, as proposed by the national policy for continuing health education. Through problematization, a new profile of care can be constructed, in which comprehensiveness is placed at the center.

\section{FINAL CONSIDERATIONS}

The methodology proposed by Augustine of Hippo is in line with Brazil's national policy for continuing education. Both frameworks define knowledge as something that cannot be transmitted and that does not belong to any person, as if it were an object. Rather, knowledge is constructed continuously based on the doubts and difficulties that arise from daily practice. In light of this, health practices must be built through a constant process, guided by different types of knowledge, linking theory and practice to provide better quality of care and enable the participation of the different actors involved in care provision.

\section{REFERENCES}

1. Agostinho. Confissões. Rio de Janeiro: Saraiva; 2012.

2. Dullo E, Freire P. O testemunho e a pedagogia católica: a ação histórica contra o fatalismo. Rev Bras Ciênc Soc [Internet]. 2014 [cited 2016 Feb 21];29(85):49-61. Available from http://www.scielo.br/pdf/rbcsoc/v29n85/04.pdf

3. Agostinho. Sobre a vida feliz. Petrópolis: Vozes; 2014.

4. Agostinho. Sobre a potencialidade da alma. Petrópolis: Vozes; 2013.

5. Brasil. Ministério da Saúde. Secretaria de Gestão do Trabalho e da Educação na Saúde, Departamento de Gestão da Educação em Saúde. Política Nacional de Educação Permanente em Saúde [Internet]. Brasília, DF: Ministério da Saúde; 2009. [cited 2016 Feb 20]. Available from: http://bvsms.saude.gov.br/bvs/publicacoes/politica_nacional_educacao_permanente_saude.pdf

6. Fernandes FC, Cortez AC. Educação permanente na reorganização do processo de trabalho em emergência: estudo exploratório. Online Braz J Nurs [Internet]. 2015 [cited 2016 Feb 18];14:415-8. Available from: http://www.objnursing.uff.br/index.php/nursing/ article/view/5362.

7. Cunha AZS, Rezende MS, Weigelt LD, Keug SBF, Feil Al. Implications of continuous education in health work process. Espaç Saúde [Internet]. 2014 [cited 2016 Jun 13];15(4):64-75. Available from: http://www.uel.br/revistas/uel/index.php/espacoparasaude/ article/view/19911/pdf_48.

8. Pinto HA, Ferla AA, Ceccim RB, Florêncio AR Barbosa MG, Stédile NLR et al. Primary Care and Continuing Health Education: scenario appointed by the National Program for Access and Quality Improvement in Primary Care PMAQ-AB. Rev Div Saúde 
Deb [Internet]. 2014 [cited 2016 Jun 13];(51):145-60. Available from: http://cebes.org.br/site/wp-content/uploads/2014/12/ Divulgacao-51.pdf.

9. Melo MC, Queluci GC, Gouvea MV. Problematizing the multidisciplinary residency in oncology: a practical teaching protocol from the perspective of nurse residents. Rev Esc Enferm USP [Internet]. 2014 [cited 2016 Feb 18];48(4):706-14.Available from: http://www.scielo.br/pdf/reeusp/v48n4/0080-6234-reeusp-48-04-706.pdf

10. Valença CN, Germano RM, Malveira FAS, Azevêdo LMN, Oliveira AG. Articulação teoria/prática na formação em saúde e a realidade do Sistema Único de Saúde. Rev Enferm UERJ [Internet]. 2014 [cited 2016 Feb 10];22(6). Available from: http://www. facenf.uerj.br/v22n6/v22n6a17.pdf 